\title{
PAPER WALLS ARE EASIER TO TEAR DOWN: PASSPORT COSTS AND LEGAL BARRIERS TO EMIGRATION
}

\author{
David J. McKenzie ${ }^{1}$ \\ Development Research Group, \\ The World Bank
}

\begin{abstract}
Increased attention to the development potential of international migration has led to calls for greater global cooperation and for developed countries to consider temporary worker programs and other options for increasing the number of immigrants admitted. However, less attention has been devoted to policies that migrant-sending countries pursue which impact on the ability of people to emigrate under the existing system. This paper documents the existence and impact of two such policies: passport costs and legal restrictions on emigration. New data collected on passport costs in 127 countries around the world reveals enormous variation in the cost of a passport from one country to the next. One in every ten countries in our sample are found to have passport costs exceeding 10 percent of annual per capita income. High passport costs are found to be associated with poor governance, especially in terms of the quality of the bureaucracy, and with lower levels of migration. Countries which place legal restrictions on the rights of women to emigrate are also found to have lower migration rates than countries with similar income and population levels. These findings suggest there is scope for some developing countries to receive greater benefits from migration by tearing down the paper walls they place around their own citizens.
\end{abstract}

JEL Classification: O15, F22.

Keywords: migration; passport costs; barriers to exit.

World Bank Policy Research Working Paper 3783, December 2005

The Policy Research Working Paper Series disseminates the findings of work in progress to encourage the exchange of ideas about development issues. An objective of the series is to get the findings out quickly, even if the presentations are less than fully polished. The papers carry the names of the authors and should be cited accordingly. The findings, interpretations, and conclusions expressed in this paper are entirely those of the authors. They do not necessarily represent the view of the World Bank, its Executive Directors, or the countries they represent. Policy Research Working Papers are available online at http://econ.worldbank.org.

1 Thanks to John Gibson, Maurice Schiff, Çaglar Özden and Alan Winters for useful comments, and to Madhur Arora, Jason Victor, and officials at the various consular departments and ministries for help in collecting the passport data. 


\section{Introduction:}

The importance of international migration for development has received increasing attention from both the research and policy communities. The United Nations Global Commission on International Migration recently issued a comprehensive report calling for greater consultation and cooperation between states and greater attention to the rights and integration needs of migrants once they arrive (GCIM, 2005). The World Bank has devoted its 2006 Global Economic Prospects report to remittances and migration, and emphasizes the importance of competition and regulation for lowering the cost of sending money transfers. Ambitious calls for greater freedom of movement under GATS Mode 4 negotiations, temporary worker programs, and other forms of bilateral or global cooperation have become part of the global policy debate.

However, far less attention has been given to barriers that countries place in the way of their own citizens who wish to emigrate. The right to emigrate is enshrined in Article 13 of the Universal Declaration of Human Rights ${ }^{2}$, but there remains a sizeable number of countries who place legal restrictions on exit, especially in the case of women. Even when no legal restrictions are in place, countries can put a sizeable burden on potential migrants through the imposition of large passport fees, and cumbersome procedures for obtaining a passport. However, little is known about the size of such fees across countries or their importance for migration.

This paper presents new data collected on passport costs in 127 countries around the world and documents the large amount of heterogeneity in costs across countries. The

\footnotetext{
${ }^{2}$ See http://www.unhchr.ch/udhr/lang/eng.htm
} 
cost of a passport is found to range from $\$ 0$ to $\$ 333^{3}$, and from 0 percent to 125 percent of annual per capita national income. Passport costs as a share of national income are higher in poorer countries, and in countries with worse measures of governance, in particular, in countries with poor bureaucracy. High passport costs are found to be associated with lower levels of migration, suggesting scope for increasing migration through domestic policy reform.

Evidence on the time costs of obtaining a passport shows differences across countries as to whether or not a passport can be obtained by post rather than in person, and in the time taken for processing a passport. High fees for expedited service are indications of the demand for more rapid processing in many countries. In addition to passport costs, this study documents legal restrictions on exit, such as requirements that citizens obtain exit visas or that women receive the permission of their husband or father to travel. Countries with restrictions on travel are shown to have lower rates of migration than countries of similar population and income levels without such restrictions.

Overall the evidence does suggest that there are real barriers placed in the way of emigration in a number of countries. Countries that wish to benefit from remittances, diaspora, technology transfer, return migration from trained nations, and other developmental impacts of migration can start by tearing down the paper walls they put around their own citizens.

\footnotetext{
${ }^{3}$ Unless indicated otherwise, all prices given in this paper are in terms of October 2005 United States Dollars.
} 
The remainder of the paper is structured as follows: Section 2 presents summary statistics on the passport data, Section 3 examines the relationship between passport costs and measures of governance and Section 4 then relates the per capita migrant stock of a country to passport costs and other determinants of migration. Section 5 summarizes the evidence on the time costs involved in obtaining a passport, Section 6 documents a number of legal restrictions on emigration and their relationship with migrant stock and Section 7 concludes.

\section{Passport Costs around the World}

Data on the cost of a passport in the country of issue was collected in October 2005. The principal form of collection was through faxes, emails and telephone calls to the consular offices of each country having an embassy or consulate office in the United States. Other sources of information included websites of passport authorities, telephone calls and faxes to the relevant government ministry in charge of issuing passports in countries, and through staff in World Bank country offices. Passport costs were collected in local currency, and converted into United States dollars at the prevailing interbank exchange rate. ${ }^{4}$ After several follow-up attempts, data were able to be collected for passport costs in 127 countries.

In many countries there is not a single passport cost. Passport costs may differ for children and adults, for first-time passports compared to renewals, and for expedited service compared to regular service. Several countries also offer the options as to the duration of the passport (for example, 1, 5 or 10 years) and as to the number of pages

\footnotetext{
${ }^{4}$ Obtained from www.oanda.com and www.xe.com.
} 
(e.g. 1000 Rupees (\$22.29) for a 36 page book or 1500 Rupees (\$33.44) for a 60 page book in India). ${ }^{5}$ Since the availability of these additional features differs across countries, an attempt to standardize was made, by collecting the price of a first-time adult passport valid for five years duration, of the standard number of pages and obtained via the standard processing period. When the country only issues a 10 -year passport, this is the price reported. ${ }^{6}$ The cost collected contains the cost of the passport itself, but not the cost of paying for photographs, birth certificates, or other such documents which are required along with the passport application.

The full list of countries and passport costs are provided in an Appendix. Figure 1 is a histogram of passport prices. It shows a wide variation in passport costs across the world. The majority of passports cost less than US\$50, with a median cost of $\$ 38.60$, the prevailing cost in Guatemala and Samoa. However, a number of countries charge over $\$ 100$ and others charge less than $\$ 10$. Table 1 lists the ten least expensive and ten most expensive countries. There is substantial geographic and economic heterogeneity amongst these. Passports are free in Armenia, only \$4.74 in Swaziland and \$4.83 in Luxembourg. Turkey, Lebanon and Chad are the most expensive, with a 5-year passport in Turkey costing $\$ 333$. Turkey does also offer a one-year passport for $\$ 130.53$, and Lebanon offers a one-year passport for $\$ 40$.

\section{Figure 1: Histogram of Passport Prices}

\footnotetext{
${ }^{5}$ In addition, the same type of passport varies slightly in price across different districts in Belgium and the Netherlands due to small district level administrative fees charged. We use typical prices for these countries, provided by the Embassies.

${ }^{6}$ One justification for not dividing the 10 -year passport price in half is that potential migrants must pay the full cost of the passport upfront.
} 


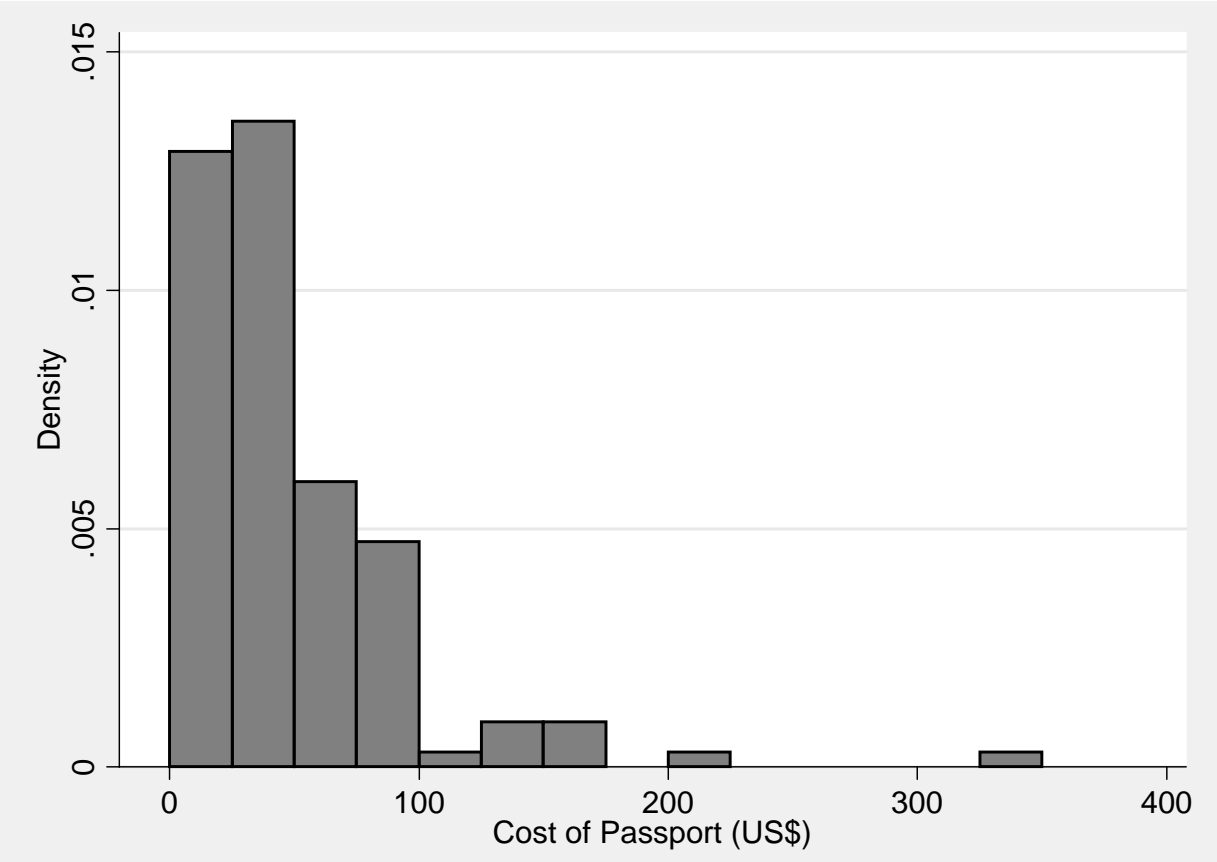

Table 1: Least and Most Expensive Passports (Cost in US Dollars)

\begin{tabular}{lcll}
\hline Least Expensive Ten Countries & Most Expensive Ten Countries & \\
\hline Armenia & 0.00 & Turkey & 333.57 \\
Swaziland & 4.74 & Lebanon & 200.00 \\
Luxembourg & 4.83 & Chad & 156.40 \\
Botswana & 5.34 & Norway & 152.34 \\
Kenya & 5.37 & Democratic Republic of Congo & 150.00 \\
Ghana & 5.45 & Denmark & 145.67 \\
Guyana & 6.30 & Bosnia-Herzegovina & 143.72 \\
Czech Republic & 8.04 & Croatia & 129.73 \\
Philippines & 8.95 & Australia & 115.22 \\
El Salvador & 9.14 & United States & 97.00 \\
\hline
\end{tabular}

Figure 2 shows that there is a general tendency for passport costs to rise with per capita incomes: an OLS regression of log passport cost on log income per capita shows that a $10 \%$ increase in per capita national income is associated with a $1.1 \%$ increase in the cost of a passport. The slope is significantly different from zero at the 5 percent level (Tstatistic of 2.34). However, Figure 2 also shows a large amount of variation around the OLS line, showing substantial differences in passport pricing policies across countries with similar income levels. 
Figure 2: Passport Costs and Per Capita Income

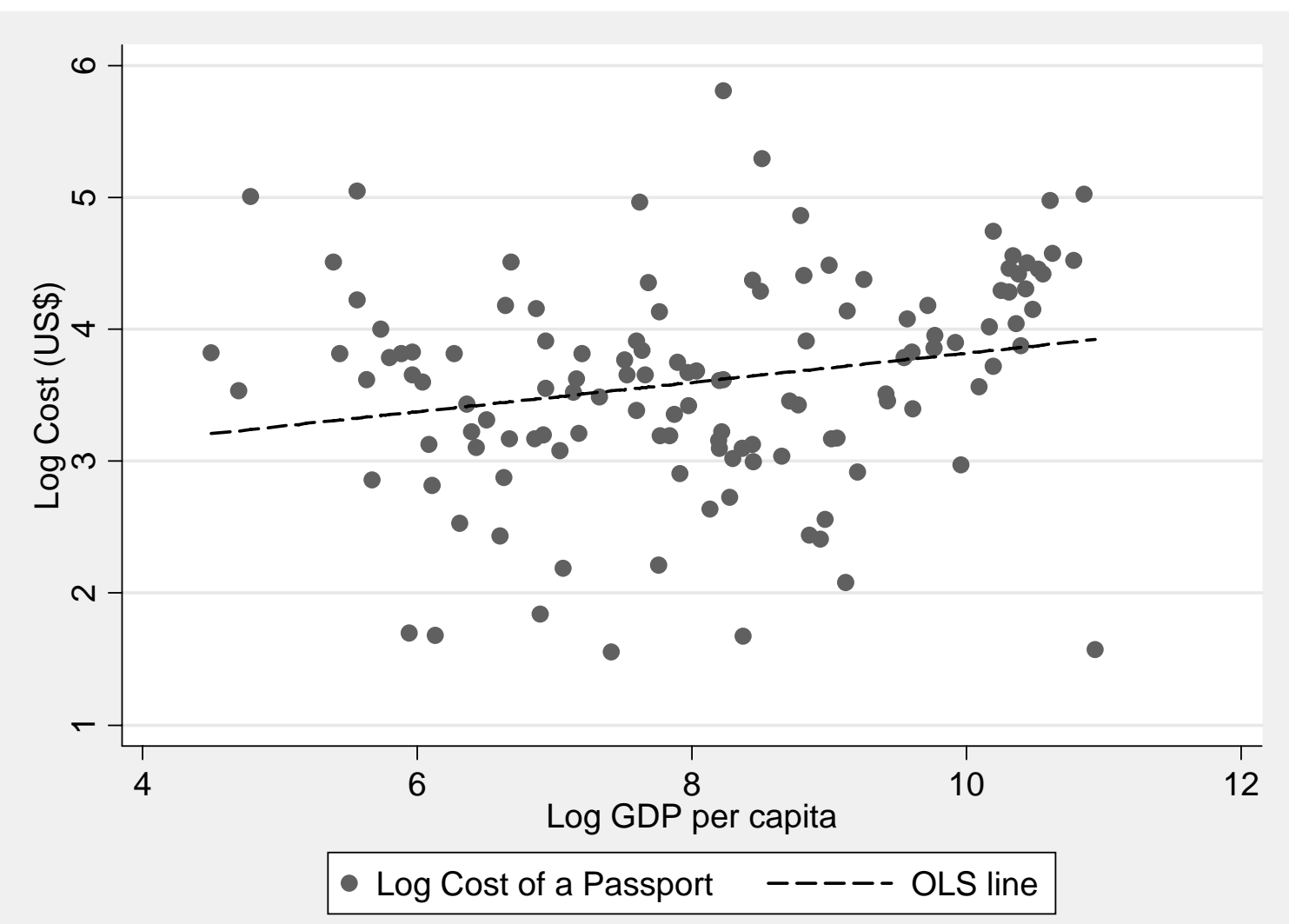

One might expect high passport costs to have much less affect on ability to migrate in high-income countries than in low-income countries. In particular, the cost of a passport relative to income may determine whether individuals are able to migrate or not. We therefore standardize passport costs by per capita Gross National Income in 2004, taken from the World Development Indicators of the World Bank. ${ }^{7}$ Table 2 then lists the 23 countries in our sample in which a passport costs 5 percent or more of annual per capita income. The most expensive passport relative to income occurs in the Democratic

\footnotetext{
${ }^{7} 2003$ GNI data was used for a few countries where 2004 GNI was not available.
} 
Republic of Congo where a passport costs 125 percent of per capita income. ${ }^{8}$ Eleven out of the fourteen countries where passport costs are 10 percent or more of annual per capita income are located in Africa. Nevertheless, other African countries manage to maintain low costs: passport costs are only $1.4 \%$ of per capita income in Ghana, $1.17 \%$ in Kenya, $0.3 \%$ in Swaziland and $0.12 \%$ in Botswana.

Table 2: Countries where a passport costs $5 \%$ or more of annual per capita income

\begin{tabular}{lclc}
\hline & \% pcGNI & & $\%$ pcGNI \\
Democratic Republic of Congo & 125.0 & Cameroon & 11.4 \\
Chad & 60.2 & Nigeria & 10.0 \\
Burundi & 50.9 & Turkey & 8.9 \\
Rwanda & 41.5 & Mauritania & 8.7 \\
Ethiopia & 31.1 & Benin & 8.6 \\
Nepal & 26.3 & Republic of Congo & 8.5 \\
Niger & 19.8 & Bosnia and Herzegovina & 7.0 \\
Central African Republic & 17.7 & Bolivia & 6.7 \\
Tanzania & 13.4 & The Gambia & 6.0 \\
Tajikistan & 13.4 & Papua New Guinea & 5.3 \\
Burkina Faso & 12.7 & Bangladesh & 5.2 \\
Lao PDR & 11.8 & & \\
\hline pcGNI = annual per capita Gross National & Income &
\end{tabular}

\section{What determines passport costs?}

Passport costs which are high relative to income are likely to act as a barrier to the ability of citizens to migrate. The question which then arises is why they are so high. One possible explanation is that passport costs are high relative to income in poorly governed countries. This may be due to poor capacity to efficiently carry out bureaucratic procedures, a repressive desire to stop citizens traveling, or to the inability to collect government revenue through standard taxation procedures. To investigate the relationship between passport costs and government, we employ the Governance IV indicators for the

\footnotetext{
${ }^{8}$ Note that in the Democratic Republic of Congo, a passport has an official price of US $\$ 80$, but the going price for an ordinary citizen is US\$150 (Source: World Bank resident mission).
} 
year 2004 from Kaufmann, Kraay and Mastruzzi (2005). They present indicators for the following six dimensions of governance:

1) Voice and Accountability: a measure of political, civil, and human rights, including the ability of citizens to participate in selection of a Government and media independence.

2) Political Stability and lack of Violence: a measure of the likelihood of the government in power being overthrown by violent or unconstitutional means.

3) Government Effectiveness: a measure of the quality of public service provision, and the competence of the bureaucracy.

4) Regulatory Quality: a measure of the incidence of market unfriendly policies and excessive regulation.

5) Rule of Law: a measure of the quality of contract enforcement, the incidence of crime, and the quality of the judiciary.

6) Control of Corruption: a measure of the use of public power for private gain, including both petty and grand corruption.

Each of the indicators is scaled to have a mean of zero and standard deviation of one, with higher scores representing better governance. Table 3 presents the results of regressing the cost of a passport relative to per capita income on these measures of governance. As the measures are quite highly correlated with one another, we include each one separately before including them jointly. Each of the different measures has a negative coefficient when entered separately, and all are significant except for voice and accountability and regulatory quality. This shows that higher passport prices relative to 
income are associated with worse governance. The largest magnitude is seen for government effectiveness, measuring the quality of the bureaucracy. A one standard deviation improvement in government effectiveness (for example, moving from Chad's level to Brazil's level) is associated with a 5 percentage point lower passport cost as a percentage of national income. Passport costs relative to income are also higher in countries with less political stability and more corruption. When we include all of the measures together, none is individually significant, reflecting the high intra-correlation.

Table 3: Do Countries with better Governance have lower passport costs?

Dependent Variable: Passport Cost as a Percentage of GNI

\begin{tabular}{|c|c|c|c|c|c|c|c|c|}
\hline & $(1)$ & (2) & (3) & $(4)$ & $(5)$ & $(6)$ & $(7)$ & (8) \\
\hline Log GNI per capita & $\begin{array}{c}-46.198 \\
(3.38)^{\star \star \star}\end{array}$ & $\begin{array}{l}-45.588 \\
(3.42)^{\star \star \star}\end{array}$ & $\begin{array}{l}-44.706 \\
(3.54)^{\star \star \star}\end{array}$ & $\begin{array}{c}-50.886 \\
(3.26)^{\star \star \star}\end{array}$ & $\begin{array}{l}-48.110 \\
(3.39)^{\star \star \star}\end{array}$ & $\begin{array}{c}-46.478 \\
(3.44)^{\star \star \star}\end{array}$ & $\begin{array}{c}-49.513 \\
(3.36)^{\star \star \star}\end{array}$ & $\begin{array}{l}-46.975 \\
(3.50)^{\star \star \star}\end{array}$ \\
\hline log GNI per capita squared & $\begin{array}{c}2.604 \\
(3.28)^{\star \star \star}\end{array}$ & $\begin{array}{c}2.614 \\
(3.29)^{\star \star \star}\end{array}$ & $\begin{array}{c}2.590 \\
(3.38)^{\star \star \star}\end{array}$ & $\begin{array}{c}3.035 \\
(3.08)^{\star \star \star}\end{array}$ & $\begin{array}{c}2.884 \\
(3.18)^{\star \star \star}\end{array}$ & $\begin{array}{c}2.726 \\
(3.21)^{\star \star \star}\end{array}$ & $\begin{array}{c}2.977 \\
(3.20)^{\star \star \star}\end{array}$ & $\begin{array}{c}2.825 \\
(3.29)^{\star \star \star}\end{array}$ \\
\hline Voice and Accountability & & $\begin{array}{l}-1.775 \\
(1.53)\end{array}$ & & & & & & $\begin{array}{l}-0.470 \\
(0.46)\end{array}$ \\
\hline Political Stability and Absence of Violence & & & $\begin{array}{l}-2.850 \\
(1.74)^{\star}\end{array}$ & & & & & $\begin{array}{l}-1.648 \\
(1.25)\end{array}$ \\
\hline Control of Corruption & & & & $\begin{array}{l}-4.036 \\
(1.83)^{\star}\end{array}$ & & & & $\begin{array}{l}1.423 \\
(0.54)\end{array}$ \\
\hline Rule of Law & & & & & $\begin{array}{l}-4.721 \\
(1.85)^{\star}\end{array}$ & & & $\begin{array}{l}-0.935 \\
(0.30)\end{array}$ \\
\hline Regulatory Quality & & & & & & $\begin{array}{l}-3.480 \\
(1.40)\end{array}$ & & $\begin{array}{l}0.393 \\
(0.15)\end{array}$ \\
\hline Government Effectiveness & & & & & & & $\begin{array}{c}-4.981 \\
(2.10)^{\star \star}\end{array}$ & $\begin{array}{l}-4.312 \\
(1.61)\end{array}$ \\
\hline Constant & $\begin{array}{l}201.528 \\
(3.51)^{\star \star \star}\end{array}$ & $\begin{array}{l}196.313 \\
(3.59)^{\star \star \star}\end{array}$ & $\begin{array}{l}190.697 \\
(3.74)^{\star \star \star}\end{array}$ & $\begin{array}{l}210.941 \\
(3.48)^{\star \star \star}\end{array}$ & $\begin{array}{l}198.901 \\
(3.64)^{\star \star \star}\end{array}$ & $\begin{array}{l}196.349 \\
(3.70)^{\star \star \star}\end{array}$ & $\begin{array}{l}204.182 \\
(3.57)^{\star \star \star}\end{array}$ & $\begin{array}{l}193.855 \\
(3.74)^{\star \star \star}\end{array}$ \\
\hline Observations & 127 & 127 & 127 & 126 & 127 & 126 & 127 & 126 \\
\hline R-squared & 0.50 & 0.51 & 0.52 & 0.52 & 0.53 & 0.52 & 0.53 & 0.53 \\
\hline
\end{tabular}

Robust t statistics in parentheses

* significant at $10 \%$; ${ }^{* *}$ significant at $5 \%,{ }^{\star \star *}$ significant at $1 \%$

\section{Are High Passport Costs a Barrier to Migration?}

The previous two sections have shown that passport costs are high relative to per capita income in some countries, and that one explanation for high passport costs is poor 
governance. We now turn to examining whether high passport costs act as a barrier to migration. We employ migration stock data based on country of birth from version 4 of the bilateral migration stock database of Parsons, Skeldon, Walmsley and Winters (2005). This quantifies migration stock based largely on the population censuses taken in 2000/01. We then calculate emigration stock as a percentage of each countries population in 2000 .

Figure 3 plots the relationship between the proportion of emigrants a country has and its passport costs. The figure is truncated at passport costs of $20 \%$ of per capita income, effectively dropping the six most expensive countries in Table $2 .{ }^{9}$ There is a clear negative relationship, with countries with higher passport costs having fewer emigrants. The only country with emigrant share above 10 percent of the population among those countries with passport costs above 5 percent of per capita income is Bosnia and Herzegovina, a clear outlier on the graph. The high emigrant share for this country is likely a result of large refugee migration as a result of the civil war in the mid-1990s.

Figure 3: Higher Passport Costs are Associated with Less Emigrants

\footnotetext{
${ }^{9}$ Of these countries, Nepal has a $2.2 \%$ migrant share, while the other countries have migrant shares under $1 \%$ (data on migrants unavailable for Ethiopia).
} 


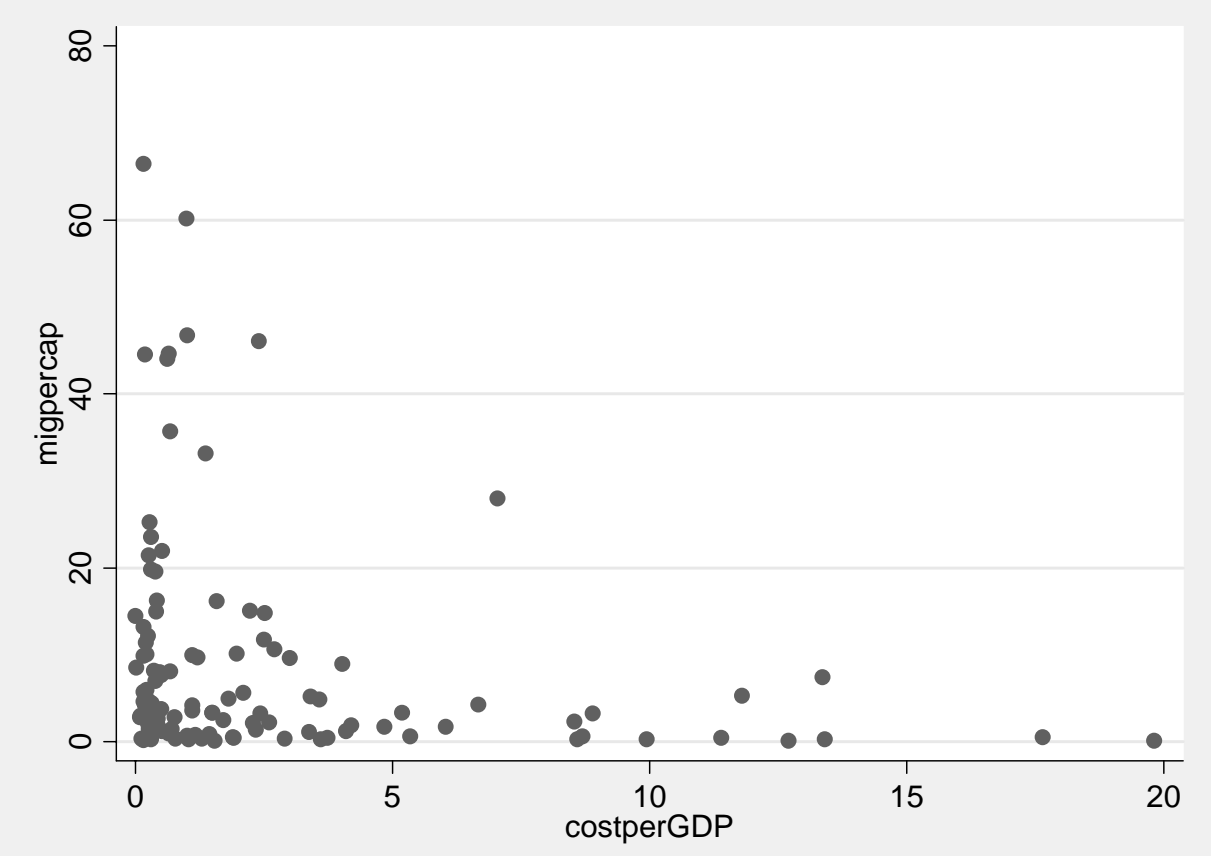

Table 4 then examines how robust the relationship seen in Figure 3 is to the inclusion of other determinants of migration which may also be correlated with passport costs. Column 1 shows that the negative relationship seen in Figure 3 is significant, although passport costs only explain a small fraction of the variation in migration. Column 2 adds log population, log national income per capita, and government effectiveness as controls. The addition of these controls causes the coefficient on passport costs to fall in magnitude, but it remains significant. One potential concern is that the relationship in Figure 3 appears nonlinear, and one may wonder whether all the results are being driven by countries with extremely high passport costs. We explore this nonlinearity in two ways. Column 3 drops countries in which passport costs are higher than 20 percent of per capita annual income, and shows that the magnitude of the coefficient on passport costs actually increases in absolute value. Columns 4 and 5 add a quadratic term in passport costs as a percentage of per capita annual income. Both specifications show evidence for 
a nonlinear effect, with a stronger effect of passport costs on emigrant stock when passport costs are below extremely high values. For countries with passport costs less than 20 percent of national income, we estimate that lowering passport costs by one percent is associated with a 0.75 percent increase in emigrants per capita. Countries with very high migration costs have less impact from a one percent decrease, since costs still remain very high. They therefore require greater reductions in costs to boost migrant numbers.

Table 4: Do Countries with Higher Passport Costs have less Emigrants? Dependent Variable: Emigrants per capita (\%)

\begin{tabular}{lccccc}
\hline & $(1)$ & $(2)$ & $(3)$ & $(4)$ & $(5)$ \\
\hline Passport Cost as \% of GNI & -0.272 & -0.156 & -0.544 & -0.757 & -0.422 \\
& $(4.09)^{\star \star \star}$ & $(2.37)^{\star \star}$ & $(2.34)^{\star \star}$ & $(3.95)^{\star \star \star}$ & $(1.51)$ \\
Passport Cost as \% of GNI Squared & & & & 0.011 & 0.005 \\
& & & & $(3.17)^{\star \star \star}$ & $(1.17)$ \\
Log of Population & & -3.700 & -3.688 & & -3.671 \\
& & $(5.64)^{\star \star \star}$ & $(5.68)^{\star \star \star}$ & & $(5.63)^{\star \star \star}$ \\
Log of GNI per capita & & $(1.193$ & 1.823 & & 1.805 \\
& & -3.840 & -4.023 & & -3.734 \\
Government Effectiveness & & $(1.97)^{\star}$ & $(2.01)^{\star \star}$ & & $(1.89)^{\star}$ \\
& & & & & \\
Constant & 9.452 & 50.391 & 54.142 & 10.372 & 53.635 \\
& $(7.39)^{\star \star \star}$ & $(3.67)^{\star \star \star}$ & $(3.61)^{\star \star \star}$ & $(7.10)^{\star \star \star}$ & $(3.54)^{\star \star \star}$ \\
Trimmed Sample & no & no & $<20 \%$ & no & no \\
p-value for test of joint significance: & & & & 0.000 & 0.083 \\
& & & & & \\
Observations & 124 & 124 & 119 & 124 & 124 \\
R-squared & 0.04 & 0.45 & 0.45 & 0.06 & 0.45 \\
\hline Nos:
\end{tabular}

Notes:

Robust t statistics in parentheses

* significant at 10\%; ** significant at $5 \%$, *** significant at $1 \%$

Column 3 trims countries with passport costs which are above $20 \%$ of per capita national income 
This analysis has examined the relationship between the stock of emigrants a country has and its current passport cost. The advantage of the emigrant stock measure is that it is based on national census and household survey data in many countries around the world. It therefore captures most of the world's legal and illegal migration. The disadvantage of this measure is that if passport costs change at different rates across countries over time, then today's passport prices may not be reflective of the relative prices prevailing at the time of emigration. Detailed migration flow data is even rarer than migration stock data ${ }^{10}$, and so we restrict our analysis to legal emigration flow into the four traditional settlement countries of the United States, Canada, Australia and New Zealand. ${ }^{11}$ The total migration flow into these four countries in 2004 is then expressed as a percentage of the sending countries 2004 population. The correlation between the emigrant stock of a country and the flow into these four countries for our sample is 0.833 .

Table 5 then repeats Table 4, using emigrant flow rather than emigrant stock as the dependent variable. The median flow into the four traditional settlement countries in 2004 was only $0.02 \%$ of the sending country population. Passport costs as a share of per capita annual income are found to be significantly related to emigration flows, in a nonlinear fashion. The size of the estimated effect is quite large: among countries with passport costs less than $20 \%$ of per capita annual income, dropping from the $75^{\text {th }}$ percentile of passport costs ( $2.5 \%$ of income) to the median ( $0.77 \%$ of income) is associated with a $0.024 \%$ increase, or doubling, of the emigration flow.

\footnotetext{
${ }^{10}$ Many countries do not break down country of origin beyond the top ten or so sending countries.

${ }^{11}$ Migration flow data collected from the Office of Immigration Statistics, Department of Homeland Security in the United States; Citizenship and Immigration Canada in Canada; the Department of Immigration and Multicultural and Indigenous Affairs in Australia; and the New Zealand Immigration Service in New Zealand.
} 
Table 5: Do Countries with Higher Passport Costs have less Emigrant Flow?

Dependent Variable: Emigrant flow per capita to USA, Canada, Australia and New Zealand in 2004 (\%)

\begin{tabular}{|c|c|c|c|c|c|}
\hline & (1) & (2) & (3) & $(4)$ & (5) \\
\hline Passport Cost as \% of GNI & $\begin{array}{c}-0.002 \\
(2.60)^{\star \star}\end{array}$ & $\begin{array}{l}-0.001 \\
(1.36)\end{array}$ & $\begin{array}{c}-0.014 \\
(2.92)^{\star \star \star}\end{array}$ & $\begin{array}{c}-0.006 \\
(4.01)^{\star \star \star}\end{array}$ & $\begin{array}{c}-0.007 \\
(2.62)^{\star \star}\end{array}$ \\
\hline Passport Cost as \% of GNI Squared & & & & $\begin{array}{c}0.000 \\
(3.63)^{\star \star \star}\end{array}$ & $\begin{array}{c}0.000 \\
(2.66)^{\star \star \star}\end{array}$ \\
\hline Log of Population & & $\begin{array}{c}-0.051 \\
(4.13)^{\star * \star}\end{array}$ & $\begin{array}{l}-0.050 \\
(4.17)^{\star \star \star}\end{array}$ & & $\begin{array}{c}-0.051 \\
(4.15)^{\star \star \star}\end{array}$ \\
\hline Log of GNI per capita & & $\begin{array}{l}0.021 \\
(0.96)\end{array}$ & $\begin{array}{l}0.000 \\
(0.02)\end{array}$ & & $\begin{array}{l}0.007 \\
(0.26)\end{array}$ \\
\hline Government Effectiveness & & $\begin{array}{l}-0.060 \\
(1.68)^{\star}\end{array}$ & $\begin{array}{l}-0.057 \\
(1.56)\end{array}$ & & $\begin{array}{l}-0.053 \\
(1.46)\end{array}$ \\
\hline Constant & $\begin{array}{c}0.118 \\
(5.45)^{\star \star \star}\end{array}$ & $\begin{array}{c}0.759 \\
(2.69)^{\star \star \star}\end{array}$ & $\begin{array}{c}0.948 \\
(2.87)^{\star \star \star}\end{array}$ & $\begin{array}{c}0.128 \\
(5.47)^{\star \star \star}\end{array}$ & $\begin{array}{c}0.889 \\
(2.81)^{\star \star \star}\end{array}$ \\
\hline $\begin{array}{l}\text { Trimmed Sample } \\
\text { p-value for test of joint significance: }\end{array}$ & no & no & $<20 \%$ & $\begin{array}{c}\text { no } \\
0.000\end{array}$ & $\begin{array}{c}\text { no } \\
0.032\end{array}$ \\
\hline Observations & 127 & 127 & 121 & 127 & 127 \\
\hline R-squared & 0.01 & 0.28 & 0.30 & 0.03 & 0.29 \\
\hline
\end{tabular}

Tables 4 and 5 have shown that countries with higher passport costs relative to income have lower stocks and flows of emigrants per capita, and that this finding is robust to the inclusion of a number of additional variables such as income and governance which might be correlated with both emigration and passport costs. Nevertheless, one should still be cautious not to interpret this result as necessarily showing that higher passport costs cause less migration to take place. A possible concern may be that the number of migrants a country has determinants the government's decision on how much to charge for a passport. ${ }^{12} \mathrm{~A}$ large number of migrants may be able to exert political pressure on

\footnotetext{
${ }^{12}$ A large absolute number of migrants may also enable economies of scale in the production of passports, lowering the marginal cost of producing a passport in terms of staffing time and office expenses.
} 
governments to keep passport costs low, or alternatively governments may see high passport costs as a way of extracting taxes from a large pool of migrants. Further research is needed to understand the political economy of passport pricing.

\section{Time Costs and Passports}

In addition to financial costs, there are also large differences across countries in the time costs involved in obtaining a passport. For approximately 40 countries we were also able to collect information on whether a first-time passport must be obtained in person, or whether it could be obtained by mailing the appropriate documents and fees. Just over a quarter of the countries providing this information allow the passport to be obtained by mail (examples include Brazil, Mauritius, the Philippines, New Zealand, and Sri Lanka). The majority of countries require their citizens to present themselves in person to apply for a passport. While there may be security reasons for requiring this, it does involve an additional cost for the potential migrant. This is particularly the case in countries where passport-issuing offices are only located in major cities, and so individuals living outside major cities must travel possibly long distances to apply for their passport. As an example, prior to the decentralization of passport issuing, citizens of Nepal had to travel to Kathmandu to obtain a passport. For people living in some areas of Nepal, this required crossing mountain ranges, clearly providing a major barrier to obtaining a passport.

The second type of time cost faced is the time taken for a passport to be issued after applying for it. This too varies widely across countries. The following are the reported 
processing times for a standard passport issue in selected countries: El Salvador 45 minutes, Pakistan 8 days, New Zealand 10 days, Australia 10 days, Ireland 2 weeks, Ghana 1 month, Bulgaria 1 month, India 5 weeks, South Africa 6 weeks, United States 6 weeks. Many countries offer the option of an expedited processing time for an extra payment. For example, Ghana charges 50,000 cedis (\$5.45) for 1 month, 500,000 cedis (\$54.45) for one week, and 1,000,000 cedis (\$108.90) for 1 day’s waiting period. Bulgaria charges 30 leva (\$18.33) for one month’s processing time, and 150 leva (\$91.65) for one day’s processing time. Long waits may also give rise to corruption with passport issuing officials accepting bribes for faster processing. For example, witnesses in a Parliamentary hearing in Namibia testified that many of the passport issuing officials would frequently shut their offices for personal business, leading to months long waits for passports and bribes of four times the cost of a passport for faster service (Philander, 2005). Although we are unable to quantify the impact of long waiting times on migration, the existence of fees up to 20 times the regular price for more rapid service does show that there is certainly demand for more efficient processing.

\section{Legal Barriers to Emigration}

In addition to price barriers, citizens in several nations also face legal barriers to obtaining a passport and to traveling out of their country. Table 6 details the 17 countries which place restrictions on the ability of women to legally obtain a passport or to travel out of their country. These restrictions take the form of preventing unmarried women traveling without the permission of their father or adult relative, and of married women traveling without the permission of their husband. Such legal restrictions coupled with 
societal pressures reduce the ability of women to migrate alone from such countries. For example, in Kuwait, where Egyptians and Syrians are among the major Arab migrant groups, Shah (2004) reports that there were twice as many migrant male Arabs as migrant females, and that only 12 percent of female Arab migrants were in the labor force, compared to 66 percent of Arab men. Most females were not working and accompanying family members. This contrasts strongly with female Asian migrants to the Gulf, who more often migrate alone as housemaids and for whom 77 percent were working.

Table 6: Walling their Women in

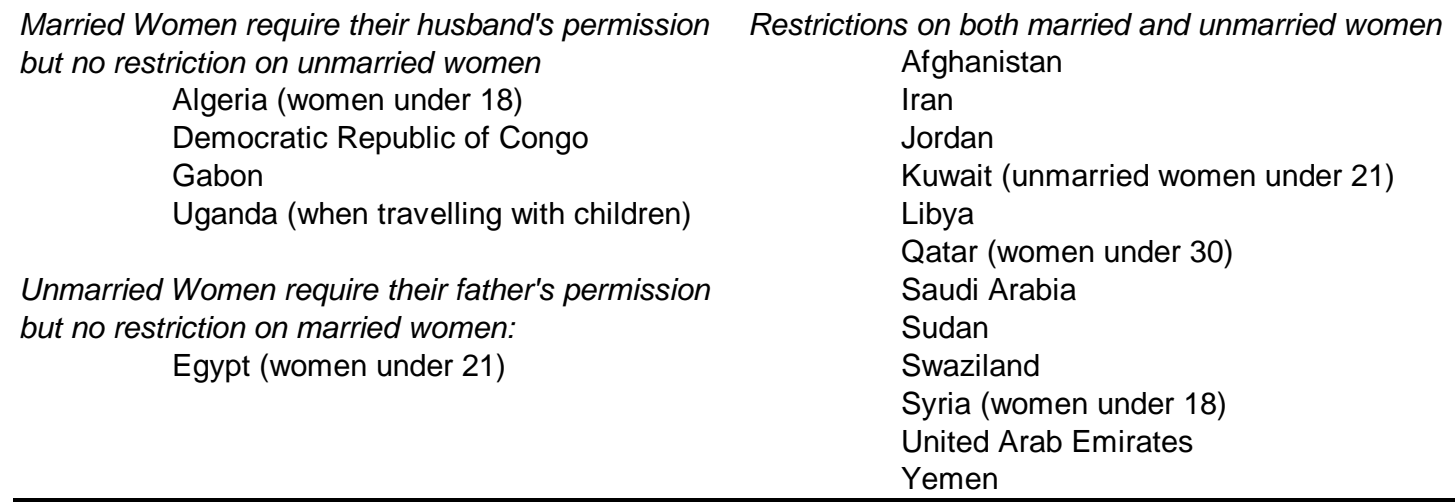

In Table 7 we examine whether the presence of these restrictions on the freedom of women to emigrate is associated with a country having fewer migrants per capita. ${ }^{13}$ Since we were unable to obtain passport costs for many of the countries with restrictions, we do not look at the joint impact of passport costs and restrictions, but instead regress migrants per capita on per capita income, the log of population, and the government effectiveness measure which was a prime determinant of passport costs. In Column 2 we also check how sensitive the results are to adding a squared term in per capita income and

\footnotetext{
${ }^{13}$ Gender disaggregated migration data is not available at a sufficient level of detail to permit testing whether these restrictions have a greater effect on female migration, as one would expect.
} 
population. The results show that these restrictions are associated with less migration. Countries which restrict the rights of women to migrate have 5 to 6 percent less migrants per capita than countries with similar income, population, and governance levels which do not have these restrictions.

Table 7: Do Restrictions on Women reduce Migration? Dependent Variable: Migrants per capita (\%)

\begin{tabular}{lcc}
\hline & $(1)$ & $(2)$ \\
\hline Restrictions on Women Emigrating & -5.956 & -5.344 \\
& $(3.30)^{\star \star \star}$ & $(3.49)^{\star \star \star}$ \\
Log of GNI per capita & 3.001 & 12.139 \\
& $(3.57)^{\star \star \star}$ & $(3.80)^{\star \star \star}$ \\
Log of Population & -3.073 & -19.390 \\
& $(5.34)^{\star \star \star}$ & $(3.18)^{\star \star \star}$ \\
Government Effectiveness & -3.421 & -1.456 \\
& $(2.38)^{\star \star}$ & $(0.94)$ \\
Log of GNI per capita squared & & -0.653 \\
& & $(2.81)^{\star \star \star}$ \\
Log of Population squared & & 0.535 \\
& & $(2.89)^{\star \star \star}$ \\
Constant & 32.744 & 125.053 \\
& $(3.27)^{\star \star \star}$ & $(2.40)^{\star \star}$ \\
Observations & 170 & 170 \\
R-squared & 0.37 & 0.47 \\
\hline Robust t statistics in parentheses & & \\
* significant at 10\%; $*$ significant at 5\%, & *** significant at $1 \%$
\end{tabular}

Table 8 details countries where two other forms of legal restrictions on movement are in force. The first is a set of countries which requires citizens to obtain government permission or an exit visa in order to be able to travel. While permission may be granted in most cases in some of these countries, the process of requiring this permission introduces additional costs and uncertainty into the migration decision. A second type of legal restriction occurs in several countries with compulsory national service, which restrict the rights of travel of citizens of national service age who have not completed 
their service requirements. Since the age of national service closely corresponds to the age range at which individuals have the greatest propensity to migrate in many countries, these restrictions may prevent the young and mobile from being able to reap the rewards of migration.

Table 8: Other Legal Restrictions on Emigration

\begin{tabular}{cc}
\hline $\begin{array}{l}\text { Government permission or an } \\
\text { exit visa required for }\end{array}$ & $\begin{array}{c}\text { Restrictions on travel of Citizens } \\
\text { of National Service Age } \\
\text { all citizens to travel }\end{array}$ \\
Belarus & Algeria \\
Cuba & Azerbaijan \\
Ecuador & Egypt \\
Equatorial Guinea & Eritrea \\
Iran & Israel \\
Laos & Kazakhstan \\
Libya & Lebanon \\
Myanmar & Singapore \\
North Korea & \\
Ukraine & \\
Uzbekistan & \\
\hline
\end{tabular}

source: Country reports of U.S. Department of State (2005)

\section{Conclusions}

There is considerable scope for global gains from increased international migration (see Walmsley and Winters (2003) for one estimate of the size of the gains). Realization of many of these gains will indeed require greater willingness on the part of migrant receiving countries to explore mechanisms which allow for greater immigration, and for coordinated bilateral and multilateral arrangements. However, this paper has shown that there is also policy latitude on the part of many migrant-sending countries to enhance the ability of their citizens to emigrate. Reduction of the cost of a passport, faster processing times, and the removal of any legal restrictions on emigration offer the potential for reaping additional gains from migration. 
This paper also focuses attention on two elements of the cost of migration. There has been considerable attention devoted recently to the costs of sending remittances and the potential gains to be had from lowering these costs. ${ }^{14}$ The formal costs of migrating have received much less attention, and there is considerable scope for further research which examines the role of formal migration costs in determining migration numbers and on the impact of policy changes in these dimensions.

\section{References:}

Gibson, John, David J. McKenzie, and Halahingano Rohorua (2005) "How Costelastic are Remittances? Evidence from Tongan Migrants in New Zealand”, Mimeo. The World Bank.

Global Commission on International Migration (2005) Migration in an interconnected world: New directions for action, Report of the Global Commission on International Migration, www.gcim.org.

Kaufmann, Daniel, Aart Kraay and Massimo Mastruzzi (2005) “Governance Matters IV: Governance Indicators for 1996-2004”, Mimeo. The World Bank

Parsons, Christopher R, Ronald Skeldon, Terrie L. Walmsley and L. Alan Winters (2005) "Quantifying the International Bilateral Movements of Migrants", Mimeo. The World Bank and the Development Research Centre on Migration, Globalisation and Poverty at Sussex University.

Philander, Frederick (2005) "Shady Deals Revealed at Home Affairs”, New Era October 10, 2005, http://allafrica.com/stories/200510100439.html [accessed November 1, 2005].

${ }^{14}$ See Gibson, McKenzie and Rohorua (2005) for a calculation of the gains from lowering remittance costs. 
Shah, Nasra M. (2004) “Arab Migration Patterns in the Gulf”, pp. 91-113 in Arab Migration in a Globalized World, International Organization for Migration (IOM): Geneva.

U.S. Department of State (2005) "2004 Country Reports on Human Rights Practices”, Bureau of Democracy, Human Rights and Labor, United States Department of State, Washington D.C. http://www.state.gov/g/drl/rls/hrrpt/2004/index.htm [accessed November 1, 2005]

Walmsley, Terrie Louise and L. Alan Winters (2003) "Relaxing the Restrictions on the Temporary Movements of Natural Persons: A Simulation Analysis,” CEPR Discussion Paper No. 3719. 
Appendix: Passport Costs Around the World

\begin{tabular}{|c|c|c|c|c|c|c|c|c|}
\hline Country & $\begin{array}{c}\text { Cost in } \\
\text { USD }\end{array}$ & $\begin{array}{c}\text { Cost as } \\
\% \text { pcGNI }\end{array}$ & Country & $\begin{array}{c}\text { Cost in } \\
\text { USD }\end{array}$ & $\begin{array}{c}\text { Cost as } \\
\% \text { pcGNI }\end{array}$ & Country & $\begin{array}{c}\text { Cost in } \\
\text { USD }\end{array}$ & $\begin{array}{l}\text { Cost as } \\
\% \text { pcGNI }\end{array}$ \\
\hline Albania & 46.46 & 2.23 & Fiji & 42.52 & 1.58 & Norway & 152.34 & 0.29 \\
\hline Angola & 50.00 & 4.85 & Finland & 48.31 & 0.15 & Oman & 12.95 & 0.16 \\
\hline Antigua and Barbuda & 18.52 & 0.19 & France & 72.46 & 0.24 & Pakistan & 25.11 & 4.19 \\
\hline Argentina & 25.20 & 0.70 & Gambia, The & 17.49 & 6.03 & Palau & 50.00 & 0.73 \\
\hline Armenia & 0.00 & 0.00 & Germany & 86.95 & 0.29 & Papua New Guinea & 31.00 & 5.34 \\
\hline Australia & 115.22 & 0.43 & Ghana & 5.45 & 1.43 & Peru & 62.41 & 2.60 \\
\hline Austria & 83.33 & 0.26 & Greece & 65.34 & 0.39 & Philippines & 8.95 & 0.76 \\
\hline Azerbaijan & 23.83 & 2.50 & Grenada & 37.41 & 0.99 & Poland & 31.72 & 0.50 \\
\hline Bahamas, The & 29.85 & 0.20 & Guatemala & 38.60 & 1.81 & Portugal & 59.00 & 0.41 \\
\hline Bahrain & 31.83 & 0.26 & Guyana & 6.30 & 0.64 & Romania & 30.66 & 1.10 \\
\hline Bangladesh & 22.83 & 5.19 & Honduras & 35.00 & 3.40 & Russian Federation & 13.99 & 0.41 \\
\hline Barbados & 62.66 & 0.68 & Hong Kong, China & 41.24 & 0.15 & Rwanda & 91.20 & 41.45 \\
\hline Belgium & 95.41 & 0.31 & Hungary & 23.85 & 0.29 & Samoa & 38.60 & 2.08 \\
\hline Belize & 15.27 & 0.39 & Iceland & 83.44 & 0.22 & Saudi Arabia & 79.99 & 0.77 \\
\hline Benin & 45.55 & 8.59 & India & 22.29 & 3.60 & Senegal & 27.51 & 4.10 \\
\hline Bhutan & 17.77 & 2.34 & Indonesia & 21.73 & 1.91 & Seychelles & 88.69 & 1.10 \\
\hline Bolivia & 64.03 & 6.67 & |reland & 90.58 & 0.26 & Singapore & 35.44 & 0.15 \\
\hline Bosnia and Herzegovina & 143.72 & 7.04 & Israel & 47.37 & 0.27 & Slovak Republic & 30.76 & 0.47 \\
\hline Botswana & 5.34 & 0.12 & |taly & 55.81 & 0.21 & Slovenia & 45.97 & 0.31 \\
\hline Brazil & 39.91 & 1.29 & Jamaica & 39.48 & 1.36 & South Africa & 23.57 & 0.65 \\
\hline Bulgaria & 18.33 & 0.67 & Japan & 86.47 & 0.23 & Spain & 19.58 & 0.09 \\
\hline Burkina Faso & 45.60 & 12.70 & Kenya & 5.37 & 1.17 & Sri Lanka & 24.58 & 2.43 \\
\hline Burundi & 45.82 & 50.91 & Korea, Rep. & 44.26 & 0.32 & St. Kitts and Nevis & 11.11 & 0.15 \\
\hline Cameroon & 91.20 & 11.40 & Lao PDR & 46.02 & 11.80 & St. Lucia & 22.22 & 0.52 \\
\hline Canada & 73.34 & 0.26 & Lebanon & 200.00 & 4.02 & St. Vincent and the Grenadines & 22.22 & 0.61 \\
\hline Central African Republic & 54.72 & 17.65 & Lesotho & 11.41 & 1.54 & Swaziland & 4.74 & 0.30 \\
\hline Chad & 156.40 & 60.15 & Lithuania & 20.91 & 0.36 & Sweden & 63.52 & 0.18 \\
\hline Chile & 73.08 & 1.49 & Luxembourg & 4.83 & 0.01 & Switzerland & 92.38 & 0.19 \\
\hline China & 37.50 & 2.90 & Malaysia & 79.57 & 1.71 & Tajikistan & 37.40 & 13.36 \\
\hline Colombia & 29.50 & 1.50 & Malta & 33.51 & 0.27 & Tanzania & 44.25 & 13.41 \\
\hline Congo, Dem. Rep. & 150.00 & 125.00 & Mauritania & 36.65 & 8.70 & Thailand & 24.39 & 1.00 \\
\hline Congo, Rep. & 65.66 & 8.53 & Mauritius & 22.88 & 0.50 & Tonga & 43.48 & 2.40 \\
\hline Costa Rica & 20.00 & 0.43 & Mexico & 82.11 & 1.21 & Trinidad and Tobago & 23.97 & 0.30 \\
\hline Croatia & 129.73 & 1.97 & Micronesia, Fed. Sts. & 50.00 & 2.51 & Tunisia & 28.70 & 1.10 \\
\hline Cyprus & 52.13 & 0.30 & Morocco & 32.62 & 2.10 & Turkey & 333.57 & 8.90 \\
\hline Czech Republic & 8.04 & 0.10 & Namibia & 24.44 & 1.03 & Ukraine & 33.97 & 2.70 \\
\hline Denmark & 145.67 & 0.36 & Nepal & 68.40 & 26.30 & United Kingdom & 74.28 & 0.22 \\
\hline Dominica & 37.04 & 1.01 & Netherlands & 56.94 & 0.18 & United States & 97.00 & 0.23 \\
\hline Ecuador & 78.00 & 3.58 & New Zealand & 49.44 & 0.24 & Vanuatu & 45.35 & 3.38 \\
\hline Egypt, Arab Rep. & 24.90 & 1.90 & Nicaragua & 23.75 & 3.01 & Venezuela, RB & 20.51 & 0.51 \\
\hline El Salvador & 9.14 & 0.40 & Niger & 45.58 & 19.82 & Vietnam & 12.57 & 2.29 \\
\hline Estonia & 11.46 & 0.16 & Nigeria & 38.79 & 9.95 & Zambia & 16.78 & 3.73 \\
\hline Ethiopia & 34.24 & 31.10 & & & & & & \\
\hline
\end{tabular}

